Zagazig J. Agric. Res., Vol. 43 No. (1) 2016

http:/www.journals.zu.edu.eg/journalDisplay.aspx? Journalld=1\&queryType=Master

\title{
EFFECT OF INTERCROPPING PATTERNS ON GROWTH, YIELD COMPONENTS, CHEMICAL CONSTITUENTS AND COMPTATION INDICES OF ONION, FENNEL AND CORIANDER PLANTS
}

\author{
Mohammed A.I. Abdelkader* and A.A.M. Mohsen \\ Hort. Dept., Fac. Agric., Zagazig Univ., Egypt
}

\begin{abstract}
This investigation aimed to study the effect of intercropping patterns of onion with fennel and coriander on growth, yield components, chemical constituents and competition indices. Simple experiment based on randomized complete block design with three replications was conducted in Agricultural Research Farm, Faculty of Agriculture, Zagazig University, Egypt during winter seasons of 2013/2014 and 2014/2015. Cropping patterns were allocated to the different planting ratios (onion: fennel or coriander as 1:1, 1:2 and 1:3) and sole onion, sole fennel and sole coriander as a control. Results revealed that alternating one row of each of fennel or coriander with three rows of onion, mostly, gave the highest values of growth parameters, yield per plant and volatile oil production as well as chemical constituents of apiaceous crops in the two seasons. Also, intercropping pattern of 1coriander:2 onion gave the highest values of onion NPK uptake and protein content per bulb. Generally, the highest values of LER (land equivalent ratio), ATER (area time equivalent ratio), LUE (land utilization efficiency) and RCC (relative crowding coefficient) were (1.206 and 1.288), (1.126 and 1.207), (113.81 and 121.99\%) and (2.552 and 4.033) in first and second seasons, respectively which were achieved by intercropping pattern of one row of coriander with two rows of onion. Also, aggressivity values indicated that apiaceous component crops (fennel or coriander) were the dominant, whereas onion was the dominated one in intercropping patterns. Generally, these mixtures seem promising in the development of sustainable crop production with a limited use of external inputs. They can be used by the farmers in Sharkia Governorate conditions as they are the most profitable systems with the greatest yield advantages.
\end{abstract}

Key words: Onion, fennel, coriander, intercropping, growth, yield, LER, ATER, LUE and RCC.

\section{INTRODUCTION}

Onion (Allium cepa L.) which belongs to family Alliaceae is one of the commercial vegetable and spice crops in Egypt, not only for local consumption but also for exportation. It considered a high cash value crop for Egyptian farmers. This is because the international market demands on the Egyptian dry, fresh and processed onions. Among the constraints for low productivity in onion, imbalanced nutrition is the main limiting factor (Shedeed et al., 2015). Sweet fennel (Foeniculum vulgare Mill.) is a plant belongs to the Umbelliferae (Apiaceae) family, which is an annual, biennial or perennial aromatic herb, depending on the variety (Farrell, 1988; Wichtl and Bisset, 1994). It is native to North Africa, Mediterranean Region, southern Europe and Asia (Abd El-Wahab and Mehasen, 2009). It contains phytochemical hormones (saponins), flavonoids, lipids, proteins and essential oils. Fennel is used in folk medicine as a stimulant, diuretic, carminative and sedative (Charles et al., 1993) and galactagogic, emmenagogic, expectorant and antispasmodic (Chiej, 1984). Coriander (Coriandrum sativum L.) is well known plant from Apiaceae family widely spread in Egypt, where it has good

\footnotetext{
* Corresponding author. Tel. : +2001008002904

Email address: mohammedahmed1980@yahoo.com
} 
climatic and soil conditions for high yield and good quality. Coriander is an aromatic herb, cultivated as a summer or winter annual crop, depending on the climatic conditions (Kofidis et al., 2008). Essential oil content is the main criteria for determining the quality of these fruits. Coriander fruits contain from 0.10 to $1.8 \%$ of essential oil (Telci et al., 2006), which has a characteristic aroma similar to a mixture of cinnamon and pepper.

Intercropping is one of the most common practices used in sustainable agricultural systems which have an important role in increasing the productivity and stability of yield in order to improve resource utilization and environmental factors such as water, nutrients and light. Among the most important benefits of intercropping is increasing the production per unit area than sole cropping (Banik et al., 2006). However, the advantage of intercropping was obtained when correspondent species were different in the form and spatiotemporal of natural resources in which different physiological and morphological characteristics will be able to make optimal use of environmental factors when cropped in the vicinity of each other.

Onion, fennel and coriander are the most important crops to be included in intercropping practices under Sharkia Governorate conditions. Therefore, the present study on intercropping of onion and other two crops was undertaken to investigate the productivity performance of onion, fennel and coriander components under different intercropping patterns compared to their sole crops and observe the yield performance of the selected component crops as sole and intercrops as well as to evaluate effectiveness of apiaceous intercrops in the management in onion bulb quality.

\section{MATERIALS AND METHODS}

This study was performed as simple experiment in randomized complete block design with three replications in Experimental Farm, Faculty of Agriculture (Ghazala Farm), Zagazig University, Egypt, during two winter seasons of 2013/2014 and 2014/2015. Thus, the present work aimed to study the effect of intercropping patterns between onion with fennel and coriander on growth, yield components and quality and chemical constituents as well as some competitive indices of the three crops.

Onion transplants (cv. Behary Improved) of nearly 45 days old were transplanted on $25^{\text {th }}$ October of both seasons and fruits of fennel and coriander components were sown in the same time. Onion was transplanted at space of $10 \mathrm{~cm}$ between hills, on two sides of the row, but fruits of both fennel and coriander were sown at space of $30 \mathrm{~cm}$ in one side of the row just after irrigation. After three weeks from planting, germinated plants were thinned to two plants/ hill for two apiaceous plants. The physical and chemical properties of the used soil are shown in Table 1.

There were 27 experimental plots each of $21.6 \mathrm{~m}^{2}$ included 12 rows; each row was $60 \mathrm{~cm}$ apart and three meters in length. Nine planting arrangements were used, each was replicated three times. The spatial arrangements were:

(1, 2 and 3) Sole onion and sole fennel as well as sole coriander, respectively,

(4) 1 row of fennel alternating with 1 row of onion,

(5) 1 row of fennel alternating with 2 rows of onion,

(6) 1 row of fennel alternating with 3 rows of onion,

(7) 1 row of coriander alternating with 1 row of onion,

(8) 1 row of coriander alternating with 2 rows of onion and

(9) 1 row of coriander alternating with 3 rows of onion.

All plants received normal agricultural practices whenever they needed. All plants were fertilized with nitrogen, phosphorus and potassium fertilization at the rate of $200 \mathrm{~kg} / \mathrm{fad}$., of ammonium sulphate $(20.5 \% \mathrm{~N}), 200 \mathrm{~kg} / \mathrm{fad}$., of calcium super phosphate $\left(15.5 \% \mathrm{P}_{2} \mathrm{O}_{5}\right)$ and $100 \mathrm{~kg} /$ fad., of potassium sulphate $\left(50 \% \mathrm{~K}_{2} \mathrm{O}\right)$, respectively. Phosphorus and potassium fertilizers were added during soil preparation as a soil dressing application. While, nitrogen fertilizer was divided into three equal portions and were added to the soil after 30, 60 and 90 days from transplanting and sowing. 
Table 1. Physical and chemical properties of experimental farm soil

\begin{tabular}{lccccc}
\hline $\begin{array}{c}\text { Physical properties } \\
(\%)\end{array}$ & $\begin{array}{c}\mathbf{2 0 1 3 / 2 0 1 4} \\
\text { season }\end{array}$ & $\begin{array}{c}\text { 2014/2015 } \\
\text { season }\end{array}$ & Chemical properties & $\begin{array}{c}\text { 2013/2014 } \\
\text { season }\end{array}$ & $\begin{array}{c}\mathbf{2 0 1 4 / 2 0 1 5} \\
\text { season }\end{array}$ \\
\hline Sand & 26.96 & 26.84 & Organic matter (\%) & 1.64 & 1.71 \\
Silt & 16.68 & 15.42 & $\mathbf{p H}$ & 7.89 & 8.10 \\
Clay & 56.36 & 57.74 & Available N (ppm) & 18.00 & 17.00 \\
Texture & \multirow{2}{*}{ Clay } & Clay & Available P (ppm) & 18.90 & 20.40 \\
& & & Available K (ppm) & 71.20 & 72.00 \\
\hline
\end{tabular}

\section{Data Recorded}

\section{Growth parameters}

At harvesting, plant height $(\mathrm{cm})$, number of leaves/plant, for onion were measured as well as plant height $(\mathrm{cm})$, number of branches/plant and total dry weight (g) for fennel and coriander were estimated by taking five random guarded plants from each experimental unit.

\section{Yield and its components}

At maturity, onion plants from each experimental unit were manually lifted, fieldcured for 15 days, in shady place before assessing bulb size. Onion bulbs were weighted, then separated into four grades according to the Ministry of Economic for onion exportation: Grade 1: bulbs with diameter more than $6 \mathrm{~cm}$, grade 2: bulbs with diameter more than 4.5 to $6 \mathrm{~cm}$, grade 3: bulbs with diameter more than 3.5 to $4.5 \mathrm{~cm}$ and grade 4: bulbs with diameter less than $3.5 \mathrm{~cm}$ and the following data were recorded: marketable yield as ton/fad. (yield of grades $1+$ $2+3$ ). Exportable yield as ton/ fad., (yield of grades $1+2$ ) and total yield as ton /fad., (yield of grades $1+2+3+4$ ) as well as average bulb weight and bulb quality as dry matter (\%) since, one hundred grams of fresh bulbs was oven dried at $105^{\circ} \mathrm{C}$ till constant weight and DM (\%) was calculated and total soluble solids (TSS) was determined in onion juice by refractometer as Brix. For fennel and coriander, umbels number/ plant and fruit yield per plant (g/plant) were determined, then total fruit yield per faddan $(\mathrm{kg} / \mathrm{fad}$.) was calculated.

\section{Chemical analyses}

Samples of dry bulbs of onion and fruits of fennel and coriander were randomly taken from each treatment for chemical analysis. Furthermore, total nitrogen uptake was determined in bulbs or fruits of each one according to the methods described by Chapman and Pratt (1978) and was multiplied by 6.25 to calculate protein (\%), then protein content was determined. Total phosphorus uptake was determined according to the methods adapted by Hucker and Catroux (1980). Potassium uptake was determined by using flame photometer according to the method described by Brown and Lilleland (1946). The volatile oil from air-dried fruits of fennel and coriander plants was isolated by hydro distillation for $3 \mathrm{hr}$., in order to extract the essential oils according to Guenther (1961) and the oil yield per plant and per faddan was calculated.

\section{Competitive indices}

\section{Land equivalent ratio (LER)}

This parameter gives an indication to the relative land area required, as sole cropping, to produce the same yields achieved by intercropping. When the LER is greater than one, the intercropping favors the growth and yield of the species. In contrast, when LER is lower than one the intercropping negatively affects the growth and yield of the plants grown in mixture. It was determined for onion, fennel and coriander yield recorded per faddan according to Mead and Willey (1980) equation as follows:

LERonion. fennel $=\mathrm{Lo}+\mathrm{Lf}$,

LERonion.coriander $=\mathrm{Lo}+\mathrm{Lc}$

$\mathrm{Lo}=\frac{\mathrm{Yof}_{\mathrm{f}}}{\mathrm{Yoo}}, \quad \mathrm{Lf}=\frac{\mathrm{Yfo}_{\mathrm{fo}}}{\mathrm{Yff}_{\mathrm{ff}}}, \quad \mathrm{Lc}=\frac{\mathrm{Yco}_{\mathrm{co}}}{\mathrm{Ycc}_{\mathrm{cc}}}$

Where Lo, Lf and Lc are the relative yield of onion, fennel and coriander, respectively, as well as Yoo, Yff and Ycc are the yields per 
faddan of onion, fennel and coriander, respectively, as sole crops and Yof, Yfo and Yco are the yields of onion and fennel as well as coriander, respectively, as intercrops.

\section{Area time equivalent ratio (ATER)}

It was calculated according to Hiebsch and McCollum (1987) equation as follows:

$$
\begin{aligned}
\text { ATER } & =\frac{Y_{0 \mathrm{f}} / Y_{0 o} \times \mathrm{to}+\mathrm{Yfo}_{\mathrm{fo}} / \mathrm{Yff}_{\mathrm{ff}}}{\mathrm{T}}, \\
\text { ATER } & =\frac{Y_{0 \mathrm{c}} / Y_{0 o} \times \mathrm{to}+Y_{\text {oc }} / Y_{\mathrm{c}} \mathrm{c} \times \mathrm{t} \mathrm{c}}{\mathrm{T}}
\end{aligned}
$$

Where: Yof $=$ intercropped yield of onion with fennel, Yoo $=$ sole yield of onion, Yfo $=$ intercropped yield of fennel, Yff = sole yield of fennel, to $=$ the duration of onion in days, $\mathrm{tf}=$ the duration of fennel in days, Yoc = intercropped yield of onion with coriander, Ycc $=$ sole yield of coriander $\mathrm{tc}=$ the duration of coriander in days, and $\mathrm{T}=$ the total duration of intercropping system in days.

\section{Land utilization efficiency (LUE\%)}

By using LER and ATER values, the land utilization efficiency (LUE \%) was calculated according to Mason et al. (1986) equation as follows:

$$
\mathrm{LUE}=\frac{\mathrm{LER} \times \mathrm{ATER}}{2} \times 100
$$

\section{Aggressivity (A)}

Aggressivity value was calculated according to Mc Gilchrist (1965) equation as follows:

1. For combination of 50:50 and 100:100, they were calculated according to the following equations:

$$
\begin{array}{ll}
\text { A of }=\mathrm{Lo}-\mathrm{Lf}, & \text { A fo }=\mathrm{Lf}-\mathrm{Lo} \\
\mathrm{A} 0 \mathrm{c}=\mathrm{L} 0-\mathrm{Lc}, & \text { A co }=\mathrm{Lc}-\mathrm{Lo}
\end{array}
$$

2. For the other combination ratios, the equations used were:

$$
\begin{aligned}
& \text { Aof }=\frac{\text { Yof }}{\text { Yoo } \times Z_{o f}}-\frac{Y_{f o}}{Y_{f f} \times Z_{f o}} \\
& \text { Afo }=\frac{Y_{f o}}{Y_{f f} \times Z_{f o}}-\frac{Y_{\text {of }}}{Y_{\text {oo }} \times Z_{\text {of }}}
\end{aligned}
$$

$$
\begin{aligned}
& \text { Aoc }=\frac{Y_{\text {oc }}}{Y_{\text {oo }} \times Z_{o c}}-\frac{Y_{c o}}{Y_{c c} \times Z_{c o}} \\
& \text { Aco }=\frac{\mathrm{Yco}_{\mathrm{co}}}{\mathrm{Ycc}_{\mathrm{cc}} \times \mathrm{Zco}_{\mathrm{coc}}}-\frac{\mathrm{Yoc}}{\mathrm{Yoo}_{\mathrm{o}} \times \mathrm{Z}_{\mathrm{cc}}}
\end{aligned}
$$

Where: Yof $=$ yield of onion intercropped with fennel, Yoc $=$ yield of onion intercropped with coriander, Yfo = intercrop yield of fennel, Yco $=$ intercropped yield of coriander, Yoo $=$ sole yield of onion, Yff $=$ sole yield of fennel, Ycc $=$ sole yield of coriander, Zof $=$ sowing proportion of onion, Zfo = sowing proportion of fennel and $\mathrm{Zco}=$ sowing proportion of coriander.

\section{Relative crowding coefficient (K)}

Another coefficient that is used, is the relative crowding coefficient $(\mathrm{K})$ which is a measure of the relative dominance of one species over the other in a mixture (De Wit, 1960). The K was calculated as:

$$
\begin{aligned}
& \mathrm{K}=(\mathrm{K} \text { onion } \times \mathrm{K} \text { fennel or coriander }), \\
& \text { Konion } \times \text { fennel }=\frac{\text { Yof Zfo }}{(\text { Yoo }- \text { Yof }) \text { Zof }}, \\
& \text { Konion } \times \text { coriander }=\frac{\text { Yoc Zco }}{(\text { Yoo - Yoc }) \text { Zoc }}, \\
& \text { Kfennel }=\frac{\text { YfoZof }}{(\text { Yff }- \text { Yfo }) Z f o}, \\
& \text { Kcoriander }=\frac{\text { Yco Zoc }}{(\text { Ycc - Yco }) \text { Zco }}
\end{aligned}
$$

Where Zof is the sown proportion of onion in mixture with fennel, Zfo is the sown proportion of fennel in mixture, Where Zoc is the sown proportion of onion in mixture with coriander and Zco is the sown proportion of coriander in mixture. When the product of the two coefficients ( $\mathrm{K}$ onion $\times \mathrm{K}$ fennel or $\times \mathrm{K}$ coriander) is greater than one, there is a yield advantage, when $\mathrm{K}$ is equal to one there is no yield advantage, and when it is less than one there is a disadvantage.

\section{Competitive ratio (CR)}

It is another way to assess competition between different species. The CR gives a better measure of competitive ability of the crops and is also advantageous as an index over K and aggressivity (Willey and Rao, 1980). The 
CR represents simply the ratio of individual LERs of the two component crops and takes into account the proportion of the crops in which they are initially sown. The CR is calculated according to the following formula:

$$
\begin{aligned}
& \text { CR onion } \times \text { fennel }=\frac{\text { LERonion }}{\text { LER fennel }}\left(\frac{Z_{f o}}{Z_{\text {of }}}\right), \\
& \text { CR onion } \times \text { coriander }=\frac{\text { LER onion }}{\text { LER coriander }}\left(\frac{Z_{\text {co }}}{Z_{o c}}\right) \\
& C R \text { fennel } \times \text { onion }=\frac{\text { LER fennel }}{\text { LER onion }}\left(\frac{Z_{\text {of }}}{Z_{\text {fo }}}\right), \\
& C R \text { coriander } \times \text { onion }=\frac{\text { LERcorander }}{\text { LER onion }}\left(\frac{Z_{\text {oc }}}{Z_{\text {co }}}\right)
\end{aligned}
$$

\section{Statistical Analysis}

All collected data were subjected to analysis of variance and means of treatments were compared with the least significant difference (LSD) test at $\mathrm{P} \leq 0.05$. The statistical calculations were performed with statistix software version 9 (Analytical software, 2008).

\section{RESULTS AND DISCUSSION}

\section{Effect of Intercropping Patterns on Onion Plant}

\section{Growth and some quality parameters}

Data presented in Table 2 reveal that, alternating one row of coriander with three rows of onion gave the highest values of onion plant height $(\mathrm{cm})$ and leaf number per plant without significant differences inbetween compared to the other ones under study during the two tested seasons. Furthermore, there was no significant increase in dry matter percentage of onion by using intercropping pattern treatments compared to sole planting pattern. However, in most cases, all intercropping patterns increased the total soluble solids (TSS), while, it decreased the average bulb weight compared to onion sole crop in first and second seasons under study.

It is now clear that using of high row ratio of onion (vs. low ratio of coriander) gave the highest values of plant height and number of leaves per plant as well as dry matter percentage without significant differences inbetween. This may be attributed to three factors. Firstly, the high population of onion plants within area unit which increased the above mentioned parameters. Secondly, the low competition between the shorter component crop (onion) and taller one (coriander) on sunlight which might be happened with decreasing the row ratio of onion plants resulting in low growth of onion. Thirdly, the low competition between coriander and onion plants on available nutrients as reported by ElShamy et al. (2008 a) on guar when intercropped with sunflower and Abdelkader et al. (2012) on guar intercropped with roselle plant.

\section{Yield and its components}

From the data recorded in Table 3, it is clear that, intercropping pattern treatments significantly decreased grade one yield, exportable yield, marketable yield and total yield per faddan compared to sole crop pattern in the first and second seasons. Moreover, alternating one row of fennel with three rows of onion treatment (1:3 pattern) recorded higher increase in grade two yield per faddan compared with the other ones under study. The maximum increase in grade three yield per faddan was obtained from the treatment of (1row of fennel: 2 rows of onion) and (1 row of fennel: 3 rows of onion) compared to sole crop and other intercropping patterns during the two tested seasons. In addition, alternating one row of coriander with three rows of onion treatment (1:3 pattern) recorded higher increase in grade four yield per feddan compared with the other ones under study.

These results agreed with those found by Abdur-Rashid and Rahmatullah (2006) on sorghum when intercropped with mungbean or guar, Mahapatra (2011) on blackgram when intercropped with sabai grass and Choudhuri and Jana (2015) on potato intercropped with mustard.

Concerning total bulb yield per faddan of onion, it was found that pure stand of onion gave the highest yield per faddan. These paradoxical results may interpreted in the light of that the highest population of onion plants within area unit (faddan) in sole onion pattern could be compensated the high of average bulb weight in this treatment compared with intercropping pattern treatments. 
Table 2. Effect of intercropping pattern treatments on onion growth, quality parameters and average bulb weight (g) during 2013/2014 and $2014 / 2015$ seasons

\begin{tabular}{|c|c|c|c|c|c|}
\hline \multirow{2}{*}{$\begin{array}{l}\text { Parameter } \\
\text { Intercropping pattern }\end{array}$} & \multicolumn{2}{|c|}{ Growth parameters } & \multicolumn{2}{|c|}{ Bulb quality } & \multirow{2}{*}{$\begin{array}{c}\text { Average } \\
\text { bulb } \\
\text { weight } \\
\text { (g) } \\
\end{array}$} \\
\hline & $\begin{array}{c}\text { Plant } \\
\text { height } \\
\text { (cm) }\end{array}$ & $\begin{array}{c}\text { Leaf } \\
\text { number / } \\
\text { plant }\end{array}$ & $\begin{array}{c}\text { Dry } \\
\text { mater } \\
(\%)\end{array}$ & $\begin{array}{c}\text { Total } \\
\text { soluble } \\
\text { solids }\end{array}$ & \\
\hline & \multicolumn{5}{|c|}{ First season (2013/2014) } \\
\hline Sole onion & $42.67 \mathrm{c}$ & 8.33 a & $14.96 \mathrm{a}$ & $10.33 \mathrm{~b}$ & 111.78a \\
\hline 1 row of fennel: 1 row of onion & 52.37ab & $9.33 \mathrm{a}$ & $15.18 \mathrm{a}$ & $12.00 \mathrm{a}$ & 102.85ab \\
\hline 1 row of fennel: 2 rows of onion & $48.67 \mathrm{bc}$ & $9.33 \mathrm{a}$ & $15.71 \mathrm{a}$ & $12.17 \mathrm{a}$ & $84.26 \mathrm{~d}$ \\
\hline 1 row of fennel: 3 rows of onion & 49.33abc & $9.33 \mathrm{a}$ & $15.04 \mathrm{a}$ & $12.67 \mathrm{a}$ & $78.81 \mathrm{~d}$ \\
\hline 1 row of coriander: 1 row of onion & 53.67ab & $8.67 \mathrm{a}$ & $14.28 \mathrm{a}$ & $12.00 \mathrm{a}$ & 96.64 c \\
\hline 1 row of coriander: 2 rows of onion & 56.00ab & $9.33 \mathrm{a}$ & $15.01 \mathrm{a}$ & $12.33 \mathrm{a}$ & 109.04ab \\
\hline \multirow[t]{2}{*}{1 row of coriander: 3 rows of onion } & 56.67 a & $10.0 \mathrm{a}$ & $15.01 \mathrm{a}$ & 12.67 a & 99.81 c \\
\hline & \multicolumn{5}{|c|}{ Second season $(2014 / 2015)$} \\
\hline Sole onion & $43.67 \mathrm{~d}$ & $7.33 \mathrm{~b}$ & $14.92 \mathrm{a}$ & $10.67 \mathrm{~b}$ & 111.77a \\
\hline 1 row of fennel: 1 row of onion & 48.67bc & $9.00 \mathrm{a}$ & $15.50 \mathrm{a}$ & 11.67ab & $102.13 \mathrm{a}$ \\
\hline 1 row of fennel: 2 rows of onion & 46.00cd & $8.67 \mathrm{a}$ & $15.07 \mathrm{a}$ & $12.00 \mathrm{ab}$ & $82.42 \mathrm{~d}$ \\
\hline 1 row of fennel: 3 rows of onion & 48.67bc & $9.00 \mathrm{a}$ & $15.32 \mathrm{a}$ & $12.00 \mathrm{ab}$ & $80.91 \mathrm{~d}$ \\
\hline 1 row of coriander: 1 row of onion & 50.00abc & $8.67 \mathrm{a}$ & $14.67 \mathrm{a}$ & $12.00 \mathrm{ab}$ & 95.98 с \\
\hline 1 row of coriander: 2 rows of onion & $52.67 \mathrm{ab}$ & $8.67 \mathrm{a}$ & $14.94 \mathrm{a}$ & 11.83ab & 111.77a \\
\hline 1 row of coriander: 3 rows of onion & 53.67 a & 9.33 a & $14.83 \mathrm{a}$ & $12.67 \mathrm{a}$ & 98.81bc \\
\hline
\end{tabular}

* Means having the same letter (s) within the same column are not significantly different according to LSD allpairwise comparisons test at $5 \%$ level of probability.

Table 3. Effect of intercropping pattern treatments on onion yield of different grades and its components (ton/ fad.) during 2013/2014 and $2014 / 2015$ seasons

\begin{tabular}{lccccccc}
\hline Parameters & Grade & Grade & Grade & Grade & Exportable Marketable & Total \\
& 1 & 2 & 3 & 4 & $\begin{array}{c}\text { yield } \\
\text { yield } \\
\text { yield }\end{array}$ \\
Intercropping pattern & & & & & $(1+2)$ & $(1+2+3)$ &
\end{tabular}

\begin{tabular}{|c|c|c|c|c|c|c|}
\hline \multirow[b]{2}{*}{ Sole onion } & \multicolumn{6}{|c|}{ First season (2013-2014) } \\
\hline & 3.864 a $2.091 b$ & $0.232 \mathrm{~b}$ & $0.184 \mathrm{~b}$ & 5.955 a & $6.186 a$ & 6.370a \\
\hline 1 row of fennel: 1 row of onion & $1.542 \mathrm{c} 1.413 \mathrm{~d}$ & $0.231 \mathrm{~b}$ & $0.069 \mathrm{~d}$ & $2.954 \mathrm{~d}$ & $3.185 \mathrm{~d}$ & 3.254de \\
\hline 1 row of fennel: 2 rows of onion & $0.963 \mathrm{~d} 1.949 \mathrm{c}$ & $0.511 \mathrm{a}$ & $0.019 \mathrm{e}$ & $2.912 \mathrm{~d}$ & $3.423 \mathrm{~d}$ & 3.441d \\
\hline 1 row of fennel: 3 rows of onion & $1.100 \mathrm{~d} 2.300 \mathrm{a}$ & $0.540 \mathrm{a}$ & $0.117 \mathrm{c}$ & $3.400 \mathrm{c}$ & $3.941 \mathrm{c}$ & $4.058 c$ \\
\hline 1 row of coriander: 1 row of onion & $1.093 \mathrm{~d} 1.399 \mathrm{~d}$ & $0.236 \mathrm{~b}$ & $0.175 b$ & $2.491 \mathrm{e}$ & $2.727 \mathrm{e}$ & $2.903 f$ \\
\hline 1 row of coriander: 2 rows of onion & $2.392 \mathrm{~b} 2.051 \mathrm{bc}$ & $0.143 \mathrm{~d}$ & $0.156 \mathrm{~b}$ & $4.444 \mathrm{~b}$ & $4.587 \mathrm{~b}$ & 4.743b \\
\hline \multirow[t]{2}{*}{1 row of coriander: 3 rows of onion } & 1.552 c $1.009 \mathrm{e}$ & $0.195 \mathrm{c}$ & $0.356 a$ & $2.561 \mathrm{e}$ & $2.756 \mathrm{e}$ & $3.111 \mathrm{ef}$ \\
\hline & \multicolumn{6}{|c|}{ Second season (2014-2015) } \\
\hline Sole o & 3.621 a 2.024 bc & $0.205 d$ & $0.170 \mathrm{~b}$ & $5.646 \mathrm{a}$ & $5.851 \mathrm{a}$ & $6.021 \mathrm{a}$ \\
\hline 1 row of fennel: 1 row of onion & 1.674 c 1.513 & $0.247 \mathrm{bc}$ & $0.055 \mathrm{~d}$ & $3.187 \mathrm{~cd}$ & $3.434 \mathrm{~d}$ & $3.532 \mathrm{~d}$ \\
\hline 1 row of fennel: 2 rows of onion & $1.020 \mathrm{~d} 1.971 \mathrm{c}$ & $0.556 \mathrm{a}$ & $0.145 b$ & 2.990de & $3.546 \mathrm{~d}$ & $3.602 \mathrm{~d}$ \\
\hline 1 row of fennel: 3 rows of onion & $1.150 d 2.266 a$ & $0.557 \mathrm{a}$ & $0.174 \mathrm{~b}$ & $3.417 \mathrm{c}$ & $3.973 \mathrm{c}$ & $4.118 \mathrm{c}$ \\
\hline 1 row of coriander: 1 row of onion & $1.006 \mathrm{~d} 1.412 \mathrm{~d}$ & $0.253 \mathrm{~b}$ & $0.174 \mathrm{~b}$ & $2.18 \mathrm{f}$ & $2.670 \mathrm{e}$ & $2.845 \mathrm{e}$ \\
\hline 1 row of coriander: 2 rows of onion & $2.468 \mathrm{~b} 2.118 \mathrm{~b}$ & 0.159 e & $0.174 \mathrm{~b}$ & $4.586 \mathrm{~b}$ & $4.745 \mathrm{~b}$ & $4.919 \mathrm{~b}$ \\
\hline 1 row of coriander: 3 rows of onion & $1.668 \mathrm{c} 1.082 \mathrm{e}$ & $0.214 \mathrm{~cd}$ & $0.375 a$ & $2.750 \mathrm{e}$ & $2.964 \mathrm{e}$ & $3.339 \mathrm{~d}$ \\
\hline
\end{tabular}

* Means having the same letter (s) within the same column are not significantly different according to LSD allpairwise comparisons test at $5 \%$ level of probability. 


\section{Chemical constituents}

The data illustrated in Table 4 indicate that, increasing number of rows of onion under cropping system with one row of fennel mostly decreased total nitrogen, phosphorus and potassium uptake per bulb as well as protein content per plant of onion. Moreover, alternating one row of coriander with two rows of onion treatment (1:2 pattern) recorded higher increase in above mentioned parameters except of potassium uptake per bulb compared with the other ones under study. These results are in accordance with those found by Megawer et al. (2010) on barley intercropped with lupine or chickpea and Nurbakhsh et al. (2013) on sesame intercropped with bean.

\section{Effect of Intercropping Patterns on Fennel Plant}

\section{Growth parameters}

Data recorded in Table 5 show that, plant height, number of branches per plant and total dry weight of fennel were increased with intercropping pattern treatments compared to sole crop pattern of fennel plant. Such increase was significant by using that of one row of fennel: three rows of onion (1:3 pattern) in both seasons. Whereas, the treatment of 1 rows of fennel: 1 row of onion (1:1) recorded lower values in this respect compared to the other two ones of intercropping pattern in both seasons. Likewise, the above mentioned parameters were increased with increasing the number of rows of onion under cropping pattern with one row of fennel. These results are in line with those reported by Meawad et al. (2003) on roselle intercropped with guar at 1:3 system, Al-Dalain (2009) on potato intercropped with maize and Sarkar and Raghav (2010) on capsicum when intercropped with maize.

\section{Yield components}

It is quite clear from the data in Table 5 that, alternating one row of fennel with two and three rows of onion treatments (1:2 and 1:3 patterns) recorded higher increase in number of umbels per plant compared with the other ones under study. Furthermore, fruit yield per plant was increased with intercropping pattern treatments compared to sole cropping pattern. Such increase was significant in the first and second seasons. In addition, fruit yield per faddan of fennel was decreased with increasing rows number of onion under cropping system with one row of fennel. However, sole crop pattern treatment increased fruit yield per faddan compared with the other intercropping planting patterns under study. Similar results were reported by Naeem et al. (2004) on sunflower intercropped with mungbean, Abdur-Rashid and Rahmatullah (2006) on sorghum when intercropped with mungbean or guar and Mahapatra (2011) on blackgram when intercropped with sabai grass.

\section{Volatile oil production and some chemical constituents}

Data in Table 6 reveal that, intercropping pattern treatments increased significantly volatile oil percentage and oil yield per plant of fennel (except that of 1:1 intercropping pattern treatment in the first season in volatile oil percentage) compared to sole crop pattern in the first and second seasons. Whereas, oil yield per faddan was significantly decreased by using intercropping pattern treatments compared to sole crop. Furthermore, alternating one row of fennel with three rows of onion treatment (1:3 pattern) recorded higher increase in volatile oil percentage and yield per plant compared with the other ones under study. These results are in harmony with those reported by Rao (2000) on java citronella intercropped with red gram, horse gram, and brinjal and Singh et al. (2002) on intercropped mint species within sugarcane.

The observed increase in volatile oil yield per faddan of sole fennel compared to intercropping patterns might be largely due to the increase in seed yield per faddan, rather than volatile oil percentage which was increased by using these treatments, as found in this study, since oil yield per faddan equal oil percentage by seed yield per faddan.

The data described in Table 6 indicate that, total nitrogen and phosphorus as well as potassium uptake per plant (g) were increased with intercropping pattern treatments compared to sole cropping pattern. Such increase was significant in the two seasons. Moreover, alternating one row of fennel with three rows of onion treatment (1:3 pattern) recorded significant increase in this respect compared with the other ones under study. Also, the abovementioned parameters were decreased with increasing rows 
Table 4. Effect of intercropping pattern treatments on some chemical constituents of onion during $2013 / 2014$ and $2014 / 2015$ seasons

\begin{tabular}{|c|c|c|c|c|}
\hline $\begin{array}{l}\text { Parameter } \\
\text { Intercropping pattern }\end{array}$ & $\begin{array}{l}\text { Nitrogen } \\
\text { uptake / } \\
\text { bulb (g) }\end{array}$ & $\begin{array}{l}\text { Phosphorus } \\
\text { uptake / } \\
\text { bulb (g) }\end{array}$ & $\begin{array}{l}\text { Potassium } \\
\text { uptake / } \\
\text { bulb (g) }\end{array}$ & $\begin{array}{l}\text { Protein } \\
\text { content / } \\
\text { bulb (g) }\end{array}$ \\
\hline & \multicolumn{4}{|c|}{ First season (2013-2014) } \\
\hline Sole onion & 3.118 a & 0.354 c & $3.060 \mathrm{a}$ & 19.489 a \\
\hline 1 row of fennel: 1 row of onion & $2.996 a b$ & $0.412 \mathrm{ab}$ & $2.774 \mathrm{bc}$ & 18.727ab \\
\hline 1 row of fennel: 2 rows of onion & $2.475 \mathrm{c}$ & $0.313 \mathrm{~d}$ & 2.356de & 15.465 c \\
\hline 1 row of fennel: 3 rows of onion & 2.362 c & $0.334 \mathrm{~cd}$ & 2.307 e & 14.763 c \\
\hline 1 row of coriander: 1 row of onion & $2.832 \mathrm{~b}$ & $0.393 \mathrm{~b}$ & 2.574cd & $17.698 \mathrm{~b}$ \\
\hline 1 row of coriander: 2 rows of onion & $3.202 \mathrm{a}$ & 0.428 a & $3.002 \mathrm{a}$ & 20.013 a \\
\hline \multirow[t]{2}{*}{1 row of coriander: 3 rows of onion } & $2.848 \mathrm{~b}$ & $0.392 \mathrm{~b}$ & 2.964ab & $17.800 \mathrm{~b}$ \\
\hline & \multicolumn{4}{|c|}{ Second season (2014-2015) } \\
\hline Sole onion & $3.083 \mathrm{~b}$ & $0.394 \mathrm{~b}$ & $3.014 \mathrm{a}$ & $19.274 \mathrm{~b}$ \\
\hline 1 row of fennel: 1 row of onion & $2.993 \mathrm{~b}$ & $0.399 \mathrm{~b}$ & 2.768ab & $18.724 \mathrm{~b}$ \\
\hline 1 row of fennel: 2 rows of onion & $2.457 \mathrm{~d}$ & $0.310 \mathrm{c}$ & $2.332 \mathrm{~d}$ & $15.337 \mathrm{~d}$ \\
\hline 1 row of fennel: 3 rows of onion & $2.413 \mathrm{~d}$ & 0.332 c & 2.376cd & $15.088 \mathrm{~d}$ \\
\hline 1 row of coriander: 1 row of onion & $2.777 \mathrm{c}$ & $0.375 \mathrm{~b}$ & $2.675 b c$ & 17.357 c \\
\hline 1 row of coriander: 2 rows of onion & 3.283 a & $0.454 \mathrm{a}$ & 3.003ab & 20.527 a \\
\hline 1 row of coriander: 3 rows of onion & $2.960 \mathrm{~b}$ & $0.398 \mathrm{~b}$ & $2.866 \mathrm{ab}$ & $18.487 \mathrm{~b}$ \\
\hline
\end{tabular}

* Means having the same letter (s) within the same column are not significantly different according to LSD allpairwise comparisons test at $5 \%$ level of probability.

Table 5. Effect of intercropping pattern treatments on fennel growth parameters and yield components during 2013/2014 and 2014/2015 seasons

\begin{tabular}{|c|c|c|c|c|c|c|}
\hline \multirow{2}{*}{$\begin{array}{l}\text { Parameter } \\
\text { Intercropping pattern }\end{array}$} & \multicolumn{3}{|c|}{ Growth parameters } & \multicolumn{3}{|c|}{ Yield components } \\
\hline & $\begin{array}{l}\text { Plant } \\
\text { height } \\
\text { (cm) }\end{array}$ & $\begin{array}{c}\text { Branch } \\
\text { number } / \\
\text { plant }\end{array}$ & $\begin{array}{l}\text { Total dry } \\
\text { weight (g) }\end{array}$ & $\begin{array}{c}\text { Umbel } \\
\text { number/ } \\
\text { plant }\end{array}$ & $\begin{array}{c}\text { Fruit } \\
\text { yield / } \\
\text { plant (g) }\end{array}$ & $\begin{array}{c}\text { Fruit yield } \\
\text { / faddan } \\
\text { (kg) }\end{array}$ \\
\hline & \multicolumn{6}{|c|}{ First season (2013-2014) } \\
\hline Sole fennel & $94.00 \mathrm{c}$ & $8.00 \mathrm{~b}$ & $72.97 \mathrm{c}$ & 45.33 c & $14.70 \mathrm{~d}$ & 653.48 a \\
\hline 1 row of fennel: 1 row of onion & $102.67 \mathrm{bc}$ & $8.67 \mathrm{~b}$ & $88.07 \mathrm{~b}$ & $57.67 \mathrm{~b}$ & $18.96 \mathrm{c}$ & $421.26 \mathrm{~b}$ \\
\hline 1 row of fennel: 2 rows of onion & 108.67ab & $9.67 \mathrm{~b}$ & 13a & 69.00 a & $21.40 \mathrm{~b}$ & $317.01 \mathrm{c}$ \\
\hline \multirow[t]{2}{*}{1 row of fennel: 3rows of onion } & 116.67 a & $12.00 \mathrm{a}$ & 112.73a & 70.33 a & 23.67a & $262.96 \mathrm{~d}$ \\
\hline & \multicolumn{6}{|c|}{ Second season (2014-2015) } \\
\hline Sole fennel & 91.67 c & $7.33 \mathrm{c}$ & $70.80 \mathrm{~d}$ & $43.33 \mathrm{c}$ & $13.63 \mathrm{~d}$ & $605.63 a$ \\
\hline 1 row of fennel: 1 row of onion & $98.00 \mathrm{~b}$ & $7.67 \mathrm{bc}$ & 84.60 c & $56.00 \mathrm{~b}$ & $18.28 \mathrm{c}$ & 406.30b \\
\hline 1 row of fennel: 2 rows of onion & $111.00 \mathrm{a}$ & $9.00 \mathrm{~b}$ & $106.27 \mathrm{~b}$ & 68.33 a & $20.43 b$ & $302.69 c$ \\
\hline 1 row of fennel: 3 rows of onion & $115.00 \mathrm{a}$ & $12.33 a$ & 116.93a & 70.67 a & $23.70 \mathrm{a}$ & 263.33d \\
\hline
\end{tabular}

* Means having the same letter (s) within the same column are not significantly different according to LSD allpairwise comparisons test at $5 \%$ level of probability. 
number of onion under cropping pattern with one row of fennel. Such results hold true in both seasons. These results are in harmony with those found by Meawad et al. (2004 a) on guar when it was intercropped with roselle and Khan et al. (2006) on sunflower, french bean, vigna radiate, soybean and cowpea when intercropped with them, as well as Abdelkader (2012) on roselle when intercropped with guar plant, regarding the increase in NPK uptake per plant due to intercropping patterns.

\section{Effect of Intercropping Patterns on Coriander Plant}

\section{Growth parameters}

The results tabulated in Table 7 clear that, alternating one row of coriander with three rows of onion recorded higher values in growth parameters of coriander plant compared to the other cropping pattern treatments under study. Furthermore, plant height, number of branches per plant and total dry weight of coriander were increased with intercropping pattern treatments compared to sole cropping pattern. In addition, the abovementioned parameters were increased with increasing the number of rows of onion under cropping pattern with one row of coriander. These results are in agreement with those reported by Ghosh et al. (2007) on tulshi (Ocimum sanctum) when intercropped in coconut, Bitew et al. (2014) on lupine intercropped with wheat, barley and finger millet and Ahmad et al. (2015) on sweet corn when intercropped with cowpea. Furthermore, the increment noticed in plant growth parameters by using intercropping pattern of one row of coriander with three rows of onion might be due to the increase in the availability of light to coriander plant, which increased metabolites of photosynthesis.

\section{Yield components}

It is evident from the results in Table 7 that, number of umbels per plant and fruit yield per fennel plant was increased, while, fruit yield per feddan was decreased with increasing rows number of onion under cropping system with one row of coriander. However, alternating one row of coriander with three rows of onion treatment (1:3 pattern) recorded significant increase in number of umbels and fruit yield per plant compared with the other ones under study.
Furthermore, fruit yield per faddan was decreased with intercropping pattern treatments compared to sole cropping pattern. Such decrease was significant in the first and second seasons. Generally, sole crop pattern treatment increased fruit yield per faddan compared with the other intercropping planting patterns under study. Similar results were found by Nurbakhsh et al. (2013) on sesame intercropped with bean and Singh et al. (2014) on mustard intercropped with lentil. In this respect, Amarasingha et al. (2015) indicated that intercropped maize yield was only $3 \%$ less than that of the maize monocrop. However, yield of mungbean was $21 \%$ less in the intercropping system than the mono-crop system.

\section{Volatile oil production and some chemical constituents}

From data presented in Table 8 it is clear that, alternating one row of coriander with three rows of onion treatment (1:3 pattern) recorded higher increase in volatile oil yield per plant compared with the other ones under study. Moreover, intercropping pattern treatments decreased significantly volatile oil percentage and oil yield per faddan of coriander crop except that of $1: 1$ and $1: 2$ patterns in volatile oil percentage in the first season compared to sole crop pattern. These results agreed with those reported by Rao (2000) on java citronella intercropped with red gram, horse gram, and brinjal and Singh et al. (2002) on intercropped mint species with in sugarcane.

The data reported in Table 8 indicate that, total nitrogen and phosphorus as well as potassium uptake per plant (g) were increased with intercropping pattern treatments except that of potassium uptake per plant in the first season compared to sole cropping pattern. Such increase was significant in the two seasons. Moreover, alternating one row of coriander with three rows of onion treatment (1:3 pattern) recorded significant increase in this respect compared with the other ones under study. Such results hold true in both seasons. These results were also found by Meawad et al. (2004 a) on guar when intercropped with roselle and Khan et al. (2006) on sunflower, french bean, Vigna radiate, soybean and cowpea when intercropped with them as well as Abdelkader et al. (2012) on roselle when intercropped with guar plant. 
Table 6. Effect of intercropping pattern treatments on volatile oil production and some chemical constituents of fennel plant during 2013/2014 and 2014/2015 seasons

\begin{tabular}{|c|c|c|c|c|c|}
\hline Parameter & Volatile & e oil production & Chen & ical constitu & uents \\
\hline Intercropping pattern & $\begin{array}{c}\text { Oil } \\
\text { percentage }\end{array}$ & $\begin{array}{l}\text { Oil yield / Oil yield / } \\
\text { plant (g) faddan } \\
\text { (kg) }\end{array}$ & $\begin{array}{c}\text { Total } \\
\text { nitrogen } \\
\text { uptake / } \\
\text { plant (g) }\end{array}$ & $\begin{array}{c}\text { Total } \\
\text { phosphorus } \\
\text { uptake / } \\
\text { plant (g) }\end{array}$ & $\begin{array}{l}\text { Potassium } \\
\text { uptake / } \\
\text { plant (g) }\end{array}$ \\
\hline
\end{tabular}

\begin{tabular}{lcccccc}
\hline & \multicolumn{7}{c}{ First season (2013-2014) } \\
Sole fennel & $3.42 \mathrm{~b}$ & $0.50 \mathrm{~d}$ & $22.38 \mathrm{a}$ & $0.227 \mathrm{~d}$ & $0.217 \mathrm{~d}$ & $0.193 \mathrm{~d}$ \\
$\mathbf{1}$ & $3.44 \mathrm{~b}$ & $0.65 \mathrm{c}$ & $14.53 \mathrm{~b}$ & $0.347 \mathrm{~b}$ & $0.370 \mathrm{~b}$ & $0.270 \mathrm{c}$ \\
$\mathbf{1}$ row of fennel: $\mathbf{1}$ row of onion & $3.70 \mathrm{a}$ & $0.79 \mathrm{~b}$ & $11.73 \mathrm{c}$ & $0.313 \mathrm{c}$ & $0.333 \mathrm{c}$ & $0.340 \mathrm{~b}$ \\
$\mathbf{1}$ row of fennel: $\mathbf{3}$ rows of onion & $3.76 \mathrm{a}$ & $0.89 \mathrm{a}$ & $9.91 \mathrm{~d}$ & $0.463 \mathrm{a}$ & $0.473 \mathrm{a}$ & $0.473 \mathrm{a}$ \\
& \multicolumn{7}{c}{ Second season $\mathbf{( 2 0 1 4 - 2 0 1 5 )}$} \\
\hline Sole fennel & $3.38 \mathrm{~d}$ & $0.45 \mathrm{~d}$ & $21.06 \mathrm{a}$ & $0.157 \mathrm{c}$ & $0.200 \mathrm{~d}$ & $0.160 \mathrm{~d}$ \\
$\mathbf{1}$ row of fennel: $\mathbf{1}$ row of onion & $3.48 \mathrm{c}$ & $0.60 \mathrm{c}$ & $15.43 \mathrm{~b}$ & $0.330 \mathrm{~b}$ & $0.373 \mathrm{~b}$ & $0.250 \mathrm{c}$ \\
$\mathbf{1}$ row of fennel: $\mathbf{2}$ rows of onion & $3.67 \mathrm{~b}$ & $0.75 \mathrm{~b}$ & $11.10 \mathrm{c}$ & $0.323 \mathrm{~b}$ & $0.347 \mathrm{c}$ & $0.232 \mathrm{~b}$ \\
$\mathbf{1}$ row of fennel: $\mathbf{3}$ rows of onion & $3.77 \mathrm{a}$ & $0.89 \mathrm{a}$ & $9.94 \mathrm{c}$ & $0.493 \mathrm{a}$ & $0.503 \mathrm{a}$ & $0.467 \mathrm{a}$ \\
\hline
\end{tabular}

* Means having the same letter (s) within the same column are not significantly different according to LSD allpairwise comparisons test at $5 \%$ level of probability.

Table 7. Effect of intercropping treatments on coriander growth parameters and yield components during 2013-2014 and $2014-2015$ seasons

\begin{tabular}{|c|c|c|c|c|c|c|}
\hline Parameter & Gro & vth param & ters & Yiel & compone & \\
\hline Intercropping pattern & $\begin{array}{c}\text { Plant } \\
\text { height } \\
\text { (cm) }\end{array}$ & $\begin{array}{c}\text { Branch } \\
\text { number / } \\
\text { plant }\end{array}$ & $\begin{array}{c}\text { Total } \\
\text { dry } \\
\text { weight } \\
\text { (g) }\end{array}$ & $\begin{array}{c}\text { Umbels } \\
\text { number / } \\
\text { plant }\end{array}$ & $\begin{array}{c}\text { Fruit } \\
\text { yield / } \\
\text { plant (g) }\end{array}$ & $\begin{array}{c}\text { Fruit } \\
\text { yield / } \\
\text { faddan } \\
\text { (kg) }\end{array}$ \\
\hline
\end{tabular}

\begin{tabular}{lcccccc}
\hline & \multicolumn{5}{c}{ First season (2013-2014) } \\
Sole coriander & $56.67 \mathrm{c}$ & $7.67 \mathrm{c}$ & $39.01 \mathrm{c}$ & $14.14 \mathrm{~d}$ & $28.00 \mathrm{~d}$ & $1244.4 \mathrm{a}$ \\
$\mathbf{1}$ row of coriander: 1 row of onion & $64.33 \mathrm{~b}$ & $13.33 \mathrm{~b}$ & $41.84 \mathrm{bc}$ & $17.38 \mathrm{c}$ & $37.00 \mathrm{c}$ & $822.2 \mathrm{~b}$ \\
$\mathbf{1}$ row of coriander: $\mathbf{2}$ rows of onion & $74.33 \mathrm{a}$ & $15.33 \mathrm{~b}$ & $44.47 \mathrm{ab}$ & $21.24 \mathrm{~b}$ & $38.67 \mathrm{~b}$ & $574.2 \mathrm{c}$ \\
$\mathbf{1}$ row of coriander: $\mathbf{3}$ rows of onion & $76.67 \mathrm{a}$ & $18.33 \mathrm{a}$ & $46.70 \mathrm{a}$ & $24.80 \mathrm{a}$ & $41.71 \mathrm{a}$ & $263.4 \mathrm{~d}$ \\
& \multicolumn{5}{c}{ Second season $\mathbf{( 2 0 1 4 - 2 0 1 5 )}$} \\
Sole coriander & $60.00 \mathrm{~d}$ & $9.33 \mathrm{~d}$ & $41.04 \mathrm{c}$ & $16.04 \mathrm{~d}$ & $28.48 \mathrm{c}$ & $1265.9 \mathrm{a}$ \\
$\mathbf{1}$ row of coriander: $\mathbf{1}$ row of onion & $64.33 \mathrm{c}$ & $14.33 \mathrm{c}$ & $43.24 \mathrm{bc}$ & $18.21 \mathrm{c}$ & $34.47 \mathrm{bc}$ & $766.0 \mathrm{~b}$ \\
$\mathbf{1}$ row of coriander: $\mathbf{2}$ rows of onion & $71.00 \mathrm{~b}$ & $16.00 \mathrm{~b}$ & $45.77 \mathrm{ab}$ & $22.55 \mathrm{~b}$ & $40.16 \mathrm{ab}$ & $595.0 \mathrm{c}$ \\
$\mathbf{1}$ row of coriander: 3 rows of onion & $78.67 \mathrm{a}$ & $19.67 \mathrm{a}$ & $48.01 \mathrm{a}$ & $25.95 \mathrm{a}$ & $43.13 \mathrm{a}$ & $479.3 \mathrm{c}$ \\
\hline
\end{tabular}

* Means having the same letter (s) within the same column are not significantly different according to LSD allpairwise comparisons test at $5 \%$ level of probability. 
Table 8. Effect of intercropping treatments on volatile oil production and some chemical constituents of coriander during 2013/2014 and 2014/2015 seasons

\begin{tabular}{|c|c|c|c|c|c|c|}
\hline Parameter & Volatil & oil produ & ction & Chen & ical consti & tuents \\
\hline Intercropping pattern & $\begin{array}{c}\text { Oil } \\
\text { percentage }\end{array}$ & $\begin{array}{c}\text { Oil yield / } \\
\text { plant (g) }\end{array}$ & $\begin{array}{c}\text { Oil yield } \\
\text { / faddan } \\
\text { (kg) }\end{array}$ & $\begin{array}{c}\text { Total } \\
\text { nitrogen } \\
\text { uptake / } \\
\text { plant (g) }\end{array}$ & $\begin{array}{c}\text { Total } \\
\text { phosphorus } \\
\text { uptake / } \\
\text { plant (g) }\end{array}$ & $\begin{array}{c}\text { Potassium } \\
\text { uptake / } \\
\text { plant (g) }\end{array}$ \\
\hline
\end{tabular}

\begin{tabular}{lcccccc} 
& \multicolumn{7}{c}{ First season (2013-2014) } \\
Sole coriander & $0.920 \mathrm{ab}$ & $0.257 \mathrm{c}$ & $11.4 \mathrm{a}$ & $0.540 \mathrm{c}$ & $0.093 \mathrm{~d}$ & $0.307 \mathrm{a}$ \\
$\mathbf{1}$ row of coriander: 1 row of onion & $0.937 \mathrm{ab}$ & $0.346 \mathrm{~b}$ & $7.70 \mathrm{~b}$ & $0.723 \mathrm{~b}$ & $0.127 \mathrm{~b}$ & $0.397 \mathrm{a}$ \\
$\mathbf{1}$ row of coriander: 2 rows of onion & $0.967 \mathrm{a}$ & $0.372 \mathrm{a}$ & $5.55 \mathrm{c}$ & $0.783 \mathrm{a}$ & $0.113 \mathrm{c}$ & $0.470 \mathrm{a}$ \\
$\mathbf{1}$ row of coriander: 3 rows of onion & $0.893 \mathrm{~b}$ & $0.375 \mathrm{a}$ & $4.14 \mathrm{~d}$ & $0.763 \mathrm{a}$ & $0.143 \mathrm{a}$ & $0.383 \mathrm{a}$ \\
& \multicolumn{7}{c}{ Second season } & $\mathbf{( 2 0 1 4 - 2 0 1 5})$ \\
\hline Sole coriander & $0.997 \mathrm{a}$ & $0.284 \mathrm{c}$ & $12.61 \mathrm{a}$ & $0.557 \mathrm{c}$ & $0.107 \mathrm{c}$ & $0.300 \mathrm{c}$ \\
$\mathbf{1}$ row of coriander: 1 row of onion & $0.953 \mathrm{~b}$ & $0.329 \mathrm{bc}$ & $7.30 \mathrm{~b}$ & $0.700 \mathrm{~b}$ & $0.140 \mathrm{~b}$ & $0.393 \mathrm{~b}$ \\
$\mathbf{1}$ row of coriander: 2 rows of onion & $0.967 \mathrm{ab}$ & $0.388 \mathrm{ab}$ & $5.75 \mathrm{c}$ & $0.747 \mathrm{~b}$ & $0.133 \mathrm{~b}$ & $0.463 \mathrm{~b}$ \\
$\mathbf{1}$ row of coriander: 3 rows of onion & $0.970 \mathrm{ab}$ & $0.418 \mathrm{a}$ & $4.65 \mathrm{c}$ & $0.903 \mathrm{a}$ & $0.193 \mathrm{a}$ & $0.567 \mathrm{a}$
\end{tabular}

* Means having the same letter (s) within the same column are not significantly different according to LSD allpairwise comparisons test at $5 \%$ level of probability.

\section{Effect of Intercropping Patterns on Competitive Indices}

\section{Land equivalent ratio (LER) and area time equivalent ratio (ATER)}

In assessments of crop productivity of sole cropping systems, a useful expression is mass yield (mass per unit area). However, in intercropping systems, direct comparison is difficult because products are different for the different plant species growing on one piece of land. In this case, crop productivity should be evaluated using a common unit. A widely used method is the land equivalent ratio (LER), Beets (1982). Therefore, area time equivalent ratio (ATER) provides more realistic comparison of the yield advantage of intercropping over sole cropping in terms of variation in time taken by the component crops of different intercropping systems, Willey (1979). LER and ATER were significantly influenced by intercropping pattern treatments (Table 9). The combined yield advantage in terms of LER and ATER indices were the greatest in the cases of 1 coriander: 2 onion intercropping arrangement (1.206, 1.288 and 1.126, 1.207) followed by 1 fennel:1 onion
(1.155, 1.259 and $1.110,1.188)$ intercropping pattern arrangement in the first and second seasons, respectively. This could be due to the reason that one to two coriander-onion as well as one to one fennel-onion intercropping arrangement planted in the same inter and intra row spacing gave compatible more efficient total resource exploitation and greater overall production than sole crops and the remaining intercropping arrangements. Whereas, 1 coriander: 3 onion (0.861, 0.935 and 0.796, 0.870), intercropping arrangements showed values less than 1.00, thus indicated the disadvantage. However, similar results were reported by Bantie (2015) on maize intercropped with potato.

Land utilization efficiency (LUE\%) and aggressivity (A)

The studied data presented in Table 9 show that, the maximum increase in land utilization efficiency (LUE\%) was obtained from the treatment of alternating one row of coriander with two rows of onion (113.81 and 121.99\%) in the first and second seasons, respectively, compared with the other ones under study. Such 
Table 9. Effect of intercropping pattern treatments on land equivalent ratio LER, area time equivalent ratio ATER, land utilization efficiency percentage LUE\% and aggrissivity values during $2013 / 2014$ and $2014 / 2015$ seasons

\begin{tabular}{|c|c|c|c|c|}
\hline Parameter & LER & $\overline{\text { ATER }}$ & LUE \% & Aggressivity \\
\hline Intercropping pattern & & & & Aao** \\
\hline
\end{tabular}

First season (2013-2014)

1 row of fennel: 1 row of onion

1 row of fennel: 2 rows of onion

1 row of fennel: 3 rows of onion

1 row of coriander: 1 row of onion

1 row of coriander: 2 rows of onion

1 row of coriander: 3 rows of onion

\section{1 row of fennel: 1 row of onion}

1 row of fennel: 2 rows of onion

1 row of fennel: 3 rows of onion

1 row of coriander: 1 row of onion

1 row of coriander: 2 rows of onion

1 row of coriander: 3 rows of onion

\begin{tabular}{|c|c|c|c|c|}
\hline $1.155 b$ & $1.110 \mathrm{a}$ & 112.19 a & $0.134 \mathrm{~d}$ & $-0.134 d$ \\
\hline $1.025 c$ & $0.975 b$ & 98.49 b & $0.647 \mathrm{~b}$ & $-0.647 b$ \\
\hline $1.040 \mathrm{c}$ & $0.980 \mathrm{~b}$ & $99.04 \mathrm{~b}$ & $0.758 a b$ & $-0.758 a b$ \\
\hline $1.117 \mathrm{~b}$ & $1.003 \mathrm{~b}$ & $101.38 b$ & $0.150 \mathrm{~d}$ & $-0.150 d$ \\
\hline $1.206 \mathrm{a}$ & $1.126 \mathrm{a}$ & $113.81 \mathrm{a}$ & $0.270 \mathrm{c}$ & $-0.270 c$ \\
\hline $0.861 \mathrm{~d}$ & $0.796 \mathrm{c}$ & 80.46 c & 0.838 a & $-0.838 a$ \\
\hline \multicolumn{5}{|c|}{ Second season (2014-2015) } \\
\hline $1.259 \mathrm{a}$ & $1.188 \mathrm{a}$ & $120.09 a$ & $0.074 \mathrm{c}$ & $-0.074 c$ \\
\hline $1.099 \mathrm{~b}$ & $1.043 b$ & $105.37 b$ & $0.602 \mathrm{~b}$ & -0.602 \\
\hline $1.121 \mathrm{~b}$ & $1.056 \mathrm{~b}$ & $106.75 b$ & $0.825 \mathrm{a}$ & $-0.825 a$ \\
\hline $1.081 \mathrm{~b}$ & $0.976 \mathrm{~b}$ & 98.65 b & $0.134 \mathrm{c}$ & -0.134 \\
\hline $1.288 \mathrm{a}$ & $1.207 \mathrm{a}$ & 121.99 a & 0.188 c & $-0.188 c$ \\
\hline 0.935 c & $0.870 \mathrm{c}$ & 87.90 c & $0.776 \mathrm{a}$ & -0.776 \\
\hline
\end{tabular}

* Means having the same letter (s) within the same column are not significantly different according to LSD allpairwise comparisons test at $5 \%$ level of probability.

** $\mathrm{a}=$ apiaceous plants (fennel and coriander) $\mathrm{o}=$ onion plant

results hold true in both seasons. While, the treatment of 1 row of coriander: 3 rows of onion recorded lower values in this respect compared to the other intercropping pattern treatments under study in both seasons.

However, Rao (2002) found that the LUE value was $128 \%$, clearly signifying the superiority of intercropping over monocropping of (either of the two crops i.e., rose-scented geranium or corn mint). In addition, the effect of intercropping pattern treatments on aggressivity (A) values of apiaceous (Aao) and onion (Aoa) calculated for fruit and bulb yield per faddan of fennel and coriander and onion, respectively. In particular, Apiaceous plants (fennel and coriander) were the dominant species (Aao positive). Whereas, onion was the dominated one (Aoa negative). Such aggressivity reached its maximum in the $1: 3$ coriander-onion intercropping pattern in the first season and that of 1:3 fennel-onion intercropping pattern in the second season.

These results were in accordance with those found, regarding the effect of intercropping treatments on aggressivity (A) values, by Meawad et al. (2004 b) suggested that roselle plants were aggressive to guar by using the intercropping system treatments of (2:1) and (3:1), whereas guar plants were aggressive to roselle by using the intercropping system treatments of (1:1) and (1:2). Azraf et al. (2006) showed that the intercropping systems of sorghum alone, sorghum + mungbean, sorghum + cluster bean, sorghum+ cowpea and sorghum + sesbania, forage sorghum appeared to be the dominant crop, as indicated by positive sign of aggressivity. El-Shamy et al. (2008 b) found that sunflower component crop was the dominant, whereas guar was the dominated one and Singh et al. (2014) on mustard intercropped with wheat and lentil. 
Relative crowding coefficient, RCC (K) and competitive ratio (CR)

Data of both seasons in Table 10 suggest that, using intercropping pattern treatments increased relative crowding coefficient RCC (K) compared to 1 coriander : 3 onion intercropping pattern during the two seasons under study. However, the highest values in this respect were achieved by using intercropping pattern of 1:2 coriander-onion which followed by $1: 1$ fennelonion intercropping pattern. Such results hold true in the first and second seasons. Competitive ratio (CR) is only used as a measure of intercrop competition (inter-specific competition) Dhima et al. (2006). CR of onion and apiaceous plants was significantly influenced by intercropping patterns. Furthermore, intercropped fennel and coriander had higher competitive ratios in all proportions with onion, indicating that apiaceous plants was more competitive (CR apiaceous > one) than onion (CR onion < one). However, in all other mixtures the values of $\mathrm{CR}$ for apiaceous (fennel and coriander) were greater than for onion indicating the dominance of apiaceous. Moreover, the CR of onion decreased, whereas the $\mathrm{CR}$ of fennel increased as the proportion increased in the mixtures. This corroborates with Trydeman et al. (2006) who stated that barley was dominant over lupine in intercrops on the sandy and sandy loam soil site, Bantie et al. (2014) on lupine intercropped with cereals and Bantie (2015) on maize intercropped with potato.

\section{Conclusion}

The present study indicated that intercropping of onion with apiaceous plants (fennel and coriander) at different intercropping patterns affected growth, yield of individual species, chemical constituents of the three species (onion and apiaceous) and also the competitive indices of the cropping system. The combined yield advantages in terms of land equivalent ratio (LER), area time equivalent ratio (ATER) and land utilization efficiency (LUE) as well as relative crowding coefficient RCC indices were greatest in the cases of 1:2 coriander-onion cropping pattern followed by 1:1 fennel-onion cropping pattern as intercropping arrangement. In addition, these two intercropping patterns were found to be the most profitable. Also apiaceous plants were the dominant species in both fennel-onion mixtures and in corianderonion mixture at all intercropping patterns under study. These mixtures seem promising in the development of sustainable crop production with a limited use of external inputs. They could be used by the farmers under Sharkia Governorate conditions as they are the most profitable systems with the greatest yield advantages.

Table 10. Effect of intercropping pattern treatments on relative crowding coefficient RCC (K) and competitive ratio CR during 2013/2014 and 2014/2015 seasons

\begin{tabular}{|c|c|c|c|}
\hline \multirow{2}{*}{$\begin{array}{l}\text { Parameter } \\
\text { Intercropping pattern }\end{array}$} & \multirow[t]{2}{*}{ RCC (K) } & \multicolumn{2}{|c|}{ Competitive ratio (CR) } \\
\hline & & CR onion & CR apiaced \\
\hline & \multicolumn{3}{|c|}{ First season (2013-2014) } \\
\hline 1 row of fennel: 1 row of onion & $1.632 \mathrm{~b}$ & $0.972 \mathrm{a}$ & $1.226 \mathrm{~d}$ \\
\hline 1 row of fennel: 2 rows of onion & $1.109 b c$ & $0.556 \mathrm{c}$ & $1.796 \mathrm{~b}$ \\
\hline 1 row of fennel: 3 rows of onion & $1.169 b c$ & $0.527 c$ & $1.899 \mathrm{~b}$ \\
\hline 1 row of coriander: 1 row of onion & $1.653 \mathrm{~b}$ & $0.690 \mathrm{~b}$ & $1.450 \mathrm{c}$ \\
\hline 1 row of coriander: 2 rows of onion & $2.552 \mathrm{a}$ & $0.808 \mathrm{a}$ & $1.244 \mathrm{~d}$ \\
\hline \multirow[t]{2}{*}{1 row of coriander: 3 rows of onion } & $0.567 \mathrm{c}$ & $0.437 \mathrm{~d}$ & $2.287 \mathrm{a}$ \\
\hline & \multicolumn{3}{|c|}{ Second season (2014-2015) } \\
\hline 1 row of fennel: 1 row of onion & $2.941 \mathrm{~b}$ & $0.902 \mathrm{a}$ & $1.118 c$ \\
\hline 1 row of fennel: 2 rows of onion & $1.526 c$ & $0.600 \mathrm{~b}$ & $1.669 \mathrm{~b}$ \\
\hline 1 row of fennel: 3 rows of onion & $1.722 c$ & $0.526 \mathrm{~b}$ & 1.910ab \\
\hline 1 row of coriander: 1 row of onion & $1.573 c$ & $0.801 \mathrm{a}$ & $1.283 c$ \\
\hline 1 row of coriander: 2 rows of onion & 4.033a & $0.871 \mathrm{a}$ & $1.153 \mathrm{c}$ \\
\hline 1 row of coriander: 3 rows of onion & $0.774 \mathrm{~d}$ & $0.492 \mathrm{~b}$ & $2.063 \mathrm{a}$ \\
\hline
\end{tabular}

* Means having the same letter (s) within the same column are not significantly different according to LSD allpairwise comparisons test at $5 \%$ level of probability. 


\section{REFERENCES}

Abdelkader, M.A.I. (2012). Effect of intercropping and fertilization on some medicinal plants. $\mathrm{Ph}$. D. Thesis, Fac. Agric., Zagazig Univ., Egypt.

Abdelkader, M.A., H.A. El-Shamy, A.A. Meawad and G.A. Bishr (2012). Yield components and active ingredients of roselle and guar as influenced by different intercropping system and nitrogen fertilization rate. Zagazig J. Agric. Res., 39 (2): 157-166.

Abd El-Wahab, M.A. and H.R. Mehasen (2009). Effect of locations and sowing date on (Foeniculum vulgare Mill.) Indian fennel type under upper Egypt conditions. J. Appl. Sci. Res., 5 (6): 677-685.

Abdur-Rashid, H.A. and K. Rahmatullah (2006). Contribution of cereal-legume association to the yield and grain quality of cereals. Pak. J. Sci. and Ind. Res., 49 (4): 290-295.

Ahmad, A.A., T.J.K. Radovich and N.V. Hue (2015). Effect of intercropping three legume species on growth and yield of sweet corn (Zea maize) in Hawaii. J. Crop Improv., 29 (3):370-378.

Al-Dalain, S.A. (2009). Effect of intercropping of Zea maize with potato (Solanum tuberosum, L.) on potato growth and on the productivity and land equivalent ratio of potato and Zea maize. Agric. J., 4: 164-170.

Amarasingha, R.K., L.D.B. Suriyagoda, B. Marambe, L.W. Galagedara, G.L.L.P. Silva, R. Punyawardena, U. Nidumolu, M. Howden, D. Parsons and H. Meinke (2015). Yield advantage and water productivity of maize-mungbean inter-cropping systems in the Dry Zone of Sri Lanka. The $17^{\text {th }}$ ASA Conf., Hobart, Australia.

Analatical software (2008). Statistix Version 9, Analytical Software, Tallahassee, Florida, USA.

Azraf, H.A., R. Ahmad, N. Mahmood and M.S. Nazir (2006). Competitive performance of associated forage crops grown different forage sorghum-legume intercropping systems. Pak. J. Agric. Sci., 43(1/2): 25-31.
Banik, P., A. Midya, B.K. Sarkar and S.S. Ghose (2006). Wheat and chickpea intercropping systems in an additive experiment. European J. Agron., 24: 325-332.

Bantie, Y.B. (2015). Determination of effective spatial arrangement for intercropping of maize (Zea mays L.) and potato (Solanum tuberosum L.) using competition indices Ethiopia. J. Hort., 2 (2):137-143.

Bantie, Y.B., F.A. Abera and T.D. Woldegiorgis (2014). Competition indices of intercropped lupine (local) and small cereals in additive series in West Gojam, North Western Ethiopia. Ame. J. Plant Sci., 5: 1296-1305.

Beets, W.C. (1982). Multiple Cropping and Tropical Farming Systems. West View Press Inc., Baulder, Colorado.

Bitew, Y., F. Abay and T. Dessalegn (2014). Effect of lupine (Lupinns spp.) intercropping and seed proportion on the yield and yield component of small cereals in North Western Ethiopia. Academic J., 9 (30): 2287-2297.

Brown, J.D. and O. Lilleland (1946). Rapid determination of potassium and sodium in plant material and soil extracts by Flame Photometry. Proc. Ame. Soc. Hort. Sci., 48: 341-46.

Chapman, D.H. and R.F. Pratt (1978). Methods of Analysis for Soil, Plant and Water. Univ. of California Div. Agric. Sci., 16: 38.

Charles, D.J., M.R. Morales and J.E. Simon (1993). Essential oil content and chemical composition of finocchio fennel. In: Janick, J. and J. E. Simon (Eds.), New crops. Wiley New York, 570-573.

Chiej, R. (1984). The Macdonald Encyclopedia of Medicinal Plants. Macdonald and Co., London.

Choudhuri, P. and J.C. Jana (2015). Growth, yield, quality and economic impacts of intercropping in potato. Agric. and Biol. Sci. J., 1 (1): 6-9.

De Wit, C.T. (1960). On competition. Verslag Landbouw-Kundige Onderzoek, 66: 1-28.

Dhima, K.V., A.S. Lithourgidis and C.A. Dordas (2006). Competition indices of 
common vetch and cereal intercrops in two seeding ratio. Field Crop Res., 100 :249-256.

El-Shamy, H.A., A.A. Meawad, G.A. Bishr and M.A. Abd El-kader (2008 a). Effect of intercropping systems of sunflower and guar on: I. Growth, yield, active ingredients and chemical constituents. Egypt. J. Appl. Sci., 23 (4A): 261-274.

El-Shamy, H.A., A.A. Meawad, G.A. Bishr and M.A. Abd-El kader (2008b). Effect of intercropping systems of sunflower and guar on: II. Land equivalent ratio and aggressivity. Egypt. J. Appl. Sci., 23 (4A): 275-285.

Farrell, K.T. (1988). Spices, Condiments and Seasonings. AVI Publ. Westport, CT., 106109.

Ghosh, D.K., A. Bandopadhyay, M.K. Maji and S. Mahapatra (2007). Studies on the performance of medicinal plants under coconut plantation in West Bengal. Indian Coconut J., 38 (8): 15-18.

Guenther, E. (1961). The Essential Oils, 1: D. Von Nostrand Comp., New York, 236.

Hiebsch, C.K. and R.E. McCollum (1987). Area $\times$ time equivalency ratio: a method for evaluating the productivity of intercrops. Agron. J., 79: 15-22.

Hucker, T.W.G. and G. Catroux (1980). Phosphorus in sewage ridge and animal waster slurries. Proceeding of the EEC Seminar, Haren (Gr); Groningen Netherlands 12, 13 June.

Khan, M.I., M.H. Shah, R. Wassem and N.A. Teeli (2006). Effect of intercropping in the soil fertility and economics of sunflower (Helianthus annuus L.) and companion legumes under temprate conditions of Kashmer. Environ. and Ecol., 245 (special 1): 171-173.

Kofidis, G., A. Giannakoula and F. Ilias (2008). Growth, anatomy and chlorophyll fluorescence of coriander plants (Coriandrum sativum L.) treated with 7 prohexadione-calcium and daminozide, Polish Academy of Sciences, Cracow. Acta Biologica Cracoviensia Series Botanica, 50 (2): 55-62.
Mahapatra, S.C. (2011). Study of grass-legume intercropping system in terms of competition indices and monetary advantage index under acid lateritic soil of India. Ame. J. Exp. Agric., 1 (1): 1- 6.

Mason, S.C., D.E. Leihner and J.J. Vorst (1986). Cassava-cowpea and cassava-peanut intercropping. 1. Yield and land use efficiency. Agron. J., 78: 43-46.

Mc Gilchrist, C.A. (1965). Analysis of competition experiments. Biometrics, 21: 975- 985.

Mead, R. and R.W. Willey (1980). The concept of a 'land equivalent ratio' and advantages in yields from intercropping. Exp. Agric., 16: 217-228.

Meawad, A.A., A.A. Helal and E.H. Amer (2003). Effect of intercropping system treatments on growth, yield components, anthocyanin production and chemical constituents of roselle plant. Zagazig J. Agric. Res. 30 (1): 129-145.

Meawad, A.A., A.A. Helal and E.H. Amer (2004 a). Effect of intercropping systems on growth, yield components, guaran production and chemical constituents of guar plant. Zagazig J. Agric. Res., 31(1): 81-96.

Meawad, A.A., A.A. Helal and E.H. Amer (2004b). Effect of intercropping systems on land equivalent ratio, aggressivity and correlation coefficients of roselle and guar. Zagazig J. Agric. Res., 31 (1): 61-79.

Megawer, E.A., A.N. Sharaan and A.M. ElSherif (2010). Effect of intercropping patterns on yield and its components of barley, lupin or chickpea grown in newly reclaimed soil. Egypt. J. Appl. Sci., 25(9): 437-452.

Naeem, M.A., F.U. Khan and A. Farooq (2004). Economics of inter-cropping sunflowermungbean at different planting patterns and dates. Sarhad J. Agric., 20 (3): 469-471.

Nurbakhsh, F., A. Koocheki and M.N. Mahallati (2013). Evaluation of yield, yield components and different intercropping indices in mixed and row intercropping of sesame (Sesamum indicum L.) and bean (Phaseolus vulgaris L.). Int. J. Agric. and Crop Sci., 17 (5):19581965. 
Rao, B.R.R. (2000). Biomass yield and essential oil yield variations in Java citronella (Cymbopogon winterianus Jowitt.), intercropped with food legumes and vegetables. J. Agron. and Crop-Sci., 185 (2): 99-103.

Rao, B.R.R. (2002). Biomass yield, essential oil yield and essential oil composition of rosescented geranium (Pelargonium species) as influenced by row spacings and intercropping with cornmint (Mentha arvensis L.f. piperascens Malinv. Ex Holmes). Ind. Crops and Prod., 16 (4): 133144.

Sarkar, M. and M. Raghav (2010). Studies on growth and flowering characteristics of capsicum in maize based intercropping system. Res. J. Agric. Sci., 1 (3): 271-272.

Shedeed, S.I., S.A.A. El-Sayed and D.M. Abo Bash (2015). Effectiveness of bio-fertilizers with organic matter on the growth, yield and nutrient content of onion (Allium сера L.) plants. European Int. J. Sci. and Technol., 3 (9): 115-122.

Singh, A.K., R.K. Singh and U. Singh (2014). Production potential and competitive indices of Indian mustard (Brassica juncea L.) based intercropping with wheat (Triticum aestivum L.) and lentil (Lens culinaris L.) under different row ratios of eastern Uttar Pradesh. Archives of Agron. and Soil Sci., 60 (2): 225-237.

Singh, U.B., S.K. Kothari and B.S. Verma (2002). Growth, yield and quality of mint species as intercrop in sugarcane under subtropical climate of north Indian plains. J. Med. and Aromatic Crops, 24 (1): 60-64.

Telci, I., O.G. Toncer and N. Sahbaz (2006). Yield, essential oil content and composition of Coriandrum sativum varieties (var. vulgare Alef and var. microcarpum DC.) grown in two different locations. J. Essent. Oil Res., 18 (2): 189-193.

Trydeman, K.M., H. Hauggaard-Nielsen, B. Jornsgard and J.E. Steen (2006). Comparison of interspecific competition and $\mathrm{N}$ use in pea-barley, faba bean-barley and lupinebarley intercrops grown at two temperate locations. J. Agric. Sci., 142: 617-627.

Wichtl, M. and N.G. Bisset (1994). Herbal drugs and phytopharmaceuticals (ed), Med. Pharm. Scientific Publ. Stuttgart, 107-108.

Willey, R.W. (1979). Intercropping, its importance and research needs. Part1. Competition and yield advantages. Agron. and Res. App. Field Crop Abs., 32: 1-10.

Willey, R.W. and M.R. Rao (1980). A competitive ratio for quantifying competition between intercrops. Exp. Agric., 16:105-117. 
تأثير نظم التحميل على النمو، المساهمات المحصولية، المحتويات الكيميائية، مؤشرات التنافس لنباتات البصل والثمر والكسبرة

$$
\text { محمد أحمد إبراهيم عبد القادر ـ أحمد عبد الله محمود محسن }
$$

يهذف هذا العمل لدراسة تأثير نظم تحميل البصل مع كل من الثمر و الكسبرة على النمو و المساهمات المحصدولية

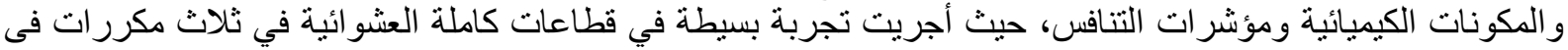

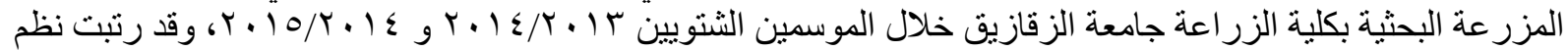

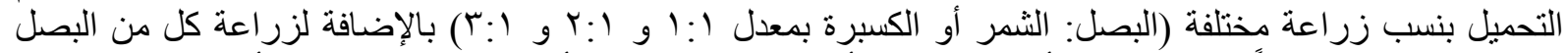

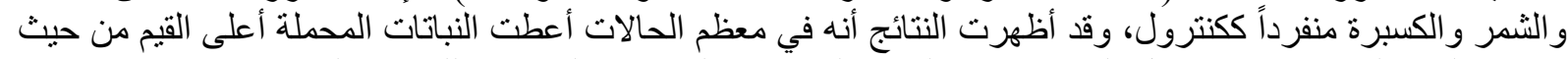

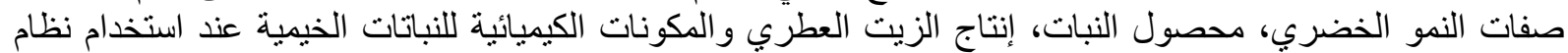

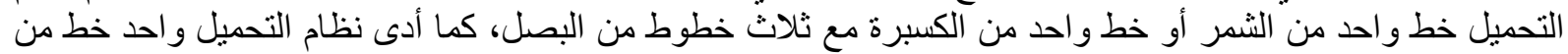

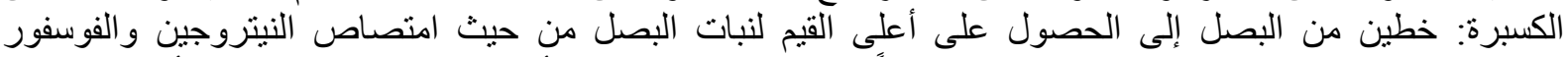

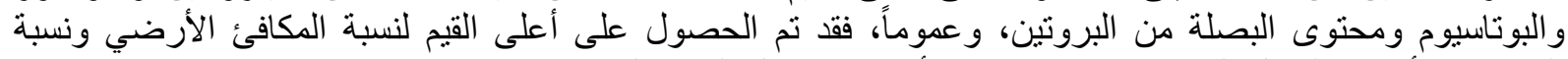

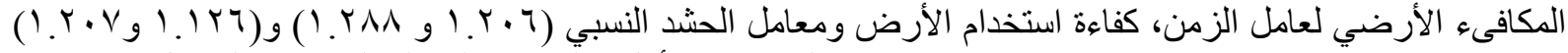

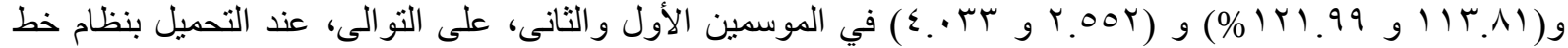

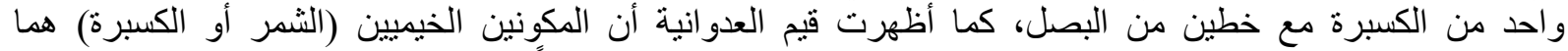

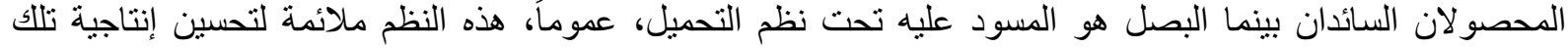

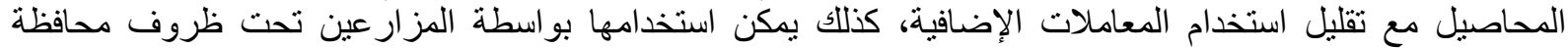
الثرقية كنظم ذات عائد مرتفع ذات ميزة محصولية.

أستاذ الخضر - كلية الزر اعة بمشتهر - جامعة بنها.

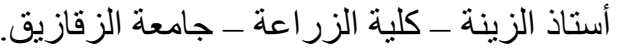

